\title{
Analysis of the type material of Pinnularia divergentissima (Grunow in VAN Heurck) Cleve (Bacillariophyceae)
}

\author{
Bart Van de ViJver ${ }^{1}$, Adéla Moravcová ${ }^{2}$, Wolf-Henning Kusber $^{3}$ \& Jiří \\ NEUSTUPA ${ }^{4}$
}

${ }^{1}$ National Botanic Garden, Department of Bryophyta \& Thallophyta, Domein van Bouchout, B-1860 Meise, Belgium; e-mail: vandevijver@brfgov.be

${ }^{2}$ Departement of Ecology, Charles University in Prague, Viničná 7, 128 44, Prague, Czech Republic

${ }_{3}^{3}$ Botanischer Garten und Botanisches Museum Berlin-Dahlem, Freie Universität Berlin, Königin-Luise-Str. 6-8, 14195, Berlin, Germany

${ }^{4}$ Departement of Botany, Charles University in Prague, Benátská 2, 12801 Prague, Czech Republic

\begin{abstract}
The analysis of the type material of Pinnularia divergentissima (Grunow in Van HeURCK) Cleve revealed the presence of two distinct Pinnularia taxa in the same slide. Comparison with the original drawing of $P$. divergentissima by GRUNOw showed that recent taxonomic treatments of $P$. divergentissima are not in accordance with the original diagnosis. Both species in the type material are morphologically characterized and the correct identity of $P$. divergentissima is established whereas the second taxon is described as $P$. pseudodivergentissima sp. nov. Additionally, the type material of $P$. fottii J.Bílý et MARVAN and P. martinii KRASSKE is likewise analysed and both taxa are separated from $P$. divergentissima. Finally, the morphological analysis of a fifth taxon from the sub-Antarctic Region resulted in the description of a new taxon, $P$. lindanedbalovae VAN DE VIJVER et MoravCOVÁ sp. nov.
\end{abstract}

Key words: Antarctic Region, landmark analysis, morphology, new species, Pinnularia divergentissima, P. fottii, P. martinii, type material

\section{Introduction}

During a survey of the diatom flora influenced by a nesting site of the wandering albatross (Diomedea exulans L.) on the subantarctic island Ile de la Possession (Crozet Archipelago, southern Indian Ocean) (Moravcová et al. 2010), several large populations of an unusual Pinnularia species were observed, showing affinities but likewise also marked differences with Pinnularia divergentissima (Grunow in VAN HeURCK) Cleve as shown in KRAMmER (2000). The species was finally identified as $P$. divergentissima and later on also observed on other islands in the southern Indian Ocean such as the Prince Edward Islands, Iles Kerguelen and Heard Island (VAN DE VIJVER et al. 2001, 2002, 2004, 2008).

Pinnularia divergentissima was originally described as Navicula divergentissima GRUNOW in Cleve et Möller (1878, and not 1879 as erroneously reported several times by various authors) reporting a list of species present in slide 186. However, this record should be considered as a nomen nudum since the name was published without a valid description nor diagnosis (ICBN art. 32; MCNeILL et al. 2006). Two years later, in VAN HEURCK (1880), GRUNOw published a drawing of $N$. divergentissima, unfortunately without citing the specimen. CLEVE (1895, p. 77) subsequently transferred the species to the genus Pinnularia. Krammer $(1992,2000)$ reinvestigated the original material of $P$. divergentissima. KRAMMER (1992) also designated a lectotype for $P$. divergentissima. However, according to art. 9.1 of the International Code of Botanical Nomenclature (McNeILL et al. 2006), the drawing of Grunow presented on plate 6, fig. 32 in VAN Heurck (1880) could be considered as the holotype ("If the author only uses one element, that one must be accepted as the holotype."). But since Grunow had used the 
new name prior to his valid publication linked to a slide deposited at Vienna (W), we use this as a strong argument for this slide being part of the original material. Therefore, Krammer's lectotypification of 1992 can be accepted, but not his taxonomic treatment of $P$. divergentissima because it does not "remain attached to that part which corresponds most nearly with the original description or diagnosis" (see McNeILL et al. 2006, art. 9.12). Additionally, several other Pinnularia species (P. fottii J.BílÝ et MARvan and P. martinii KRASSKE) were included within the concept of $P$. divergentissima by KRAMMER (1992) as synonyms.

In general, $P$. divergentissima is characterized in having relatively small valve dimensions (length less than $40 \mu \mathrm{m}$ ), the absence of external longitudinal lines on the striae and the presence of a distinct shift in stria orientation about halfway the central area and the valve apex. A similar shift can be observed in only a few other species such as $P$. acoricola Hust. (Hustedt 1935; Luís et al. 2012), P. similiformis Krammer (Krammer 1992), and P. carteri Krammer (KRAmmer 2000) but is absent in the majority of Pinnularia species.

When comparing $P$. divergentissima specimens in the type slide (slide 186 from the Collection of Cleve \& Möller in the Grunow Collection in the Naturhistorisches Museum, Vienna, Austria, W), with the original drawing made by Grunow (kept at the National Botanic Garden of Belgium), it was clear that there were actually two species present in the slide showing comparable morphological features. Moreover, comparing the original drawing and the specimens related to this drawing from the Cleve \& Möller slide, with the illustrations shown by KRAMMER (1992, 2000) taken from slide 186 from the Collection of Cleve \& Möller (present at W), it was clear that $P$. divergentissima as Grunow described it and the specimens identified by KRAMMER (2000) as P. divergentissima do not belong to the same species. KRAMMER (1992) overlooked the admixture of two taxa and illustrated a single valve not corresponding to Grunow's original drawing. Therefore, the illustrations shown by KrAMMER $(1992,2000)$ belong to an undescribed species whereas only the specimens resembling Grunow's original drawing in KRAMMER (2000, plate 11, fig. 1) should be considered as the real $P$. divergentissima.

The present paper discusses the results of a comparison between several species resembling
P. divergentissima based on detail morphological observations and classical measurements of the type material. A reanalysis of the Cleve \& Möller 186 slide resulted in the separation of the real $P$. divergentissima specimens from the second species present in the slide, describing the latter as a new species: Pinnularia pseudodivergentissima sp. nov. In addition to the analysis of the material of $P$. divergentissima, the type material of $P$. fottii and P. martinii, considered by Krammer $(1992,2000)$ as synonyms of $P$. divergentissima and some of its varieties, are likewise investigated. For a precise illustration of the quantitative morphological differences between individual taxa, we used the landmark-based geometric morphometrics of valve shapes (Potapova \& Hamilton 2007; Veselá et al. 2009). With the geometric-morphometric registration of valve shapes, we were also able to identify the position of the original Grunow's type drawing of $P$. divergentissima in the morphospace so that the most similar specimens from the Cleve \& Möller 186 slide could be determined. Finally, the sub-Antarctic species is described as a new species Pinnularia lindanedbalovae VAN DE ViJver et Moravcová sp. nov.

\section{Material and Methods}

Sample preparation. For this study, the type material of several small Pinnularia species belonging to the complex of $P$. divergentissima was investigated:

- Navicula divergentissima GRUNOw in CLEve et Möller 1879, slide 186, Fogstuen, Dovre, Norway (collected by Mr. O. Nordstedt) in the Grunow Collection (Lectotype slide present in the Naturhistorisches Museum, Vienna, Austria, W) and the Van Heurck Collection in the National Botanic Garden of Belgium (Belgium), BR (slide coll. $\mathrm{n}^{\circ}$ II-7-B2)

- Pinnularia fottii J.Bílý et Marvan 1959, slide 575B IOK, Věčný déšt', Vysoké Tatry, Slovakia in the herbarium of the Botanical Institute of the Masaryk University, Brno (Czech Republic)

- Pinnularia martinii KRASSKe 1939, slide 4165 S. Vincente, Brandungshöhlen von Ramuncho, Krasske Collection, Kassel (Germany)

Additional material used in this study was collected on the sub-Antarctic island Ile de la Possession (Crozet Archipelago, southern Indian Ocean). Samples were taken from soils at the Champs des Albatros at Pointe Basse during the austral summer of 2004-2005. Details about the samples and the sampling location can be found in VAN DE ViJVER et al. (2002) and MoraVCOVÁ et 
al. (2010). All soil samples were stored in $25 \mathrm{ml}$ PVC bottles and fixed immediately with 3\% formaldehyde. Diatom slides were prepared following the method described in VAN DER WERFF (1955). A small subsample was treated with $\mathrm{H}_{2} \mathrm{O}_{2}$ and $\mathrm{KMnO}_{4}$ in order to remove all organic material. To speed up the reaction, samples were heated on a boiling plate for a short period. Following centrifugation, the resulting clean material was diluted with distilled water to avoid excessive concentrations of diatom valves that might obstruct the counting. Cleaned diatom valves were mounted in Naphrax ${ }^{\circledR}$. Light microscopical observations were performed using an Olympus BX51 microscope equipped with Differential Interference Contrast optics $\left(\right.$ Nomarski $\left.{ }^{\circledR}\right)$. Samples and slides are stored at the Department of Bryophyta and Thallophyta at the National Botanic Garden of Belgium in Meise. For scanning electron microscopy (SEM), part of the suspension was filtered through polycarbonate membrane filters with a pore diameter of $3 \mu \mathrm{m}$, pieces of which were fixed on aluminium stubs after airdrying. The stubs were sputter-coated with $50 \mathrm{~nm}$ of gold and studied in a JEOL-5800LV at $20 \mathrm{kV}$.

Morphological terminology follows Hendey (1964), Round et al. (1990) and KRAMMER (2000).

Geometric morphometrics. In total, 42 landmarks were delimited on valvar views of 335 Pinnularia frustules (Fig. 1) using TpsDig, ver. 2.16. (RoHLF 2010a). Landmarks were mostly placed along the valve outline, but they were also located in the central area, and at the raphe and stria endings. Of these 42 landmarks, there were 28 landmarks located in fixed

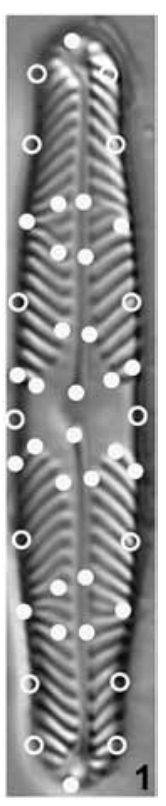

Fig. 1. Pinnularia divergentissima. Positions of the landmark with fixed landmarks represented by empty circles and semilandmarks by filled circles. positions and 14 landmarks were allowed to slide along the abscissa connecting adjacent points (BoOKSTEIN 1991) (Fig. 1). As the apical ends of the valves could not be unambiguously identified, all the valves were symmetrised along the apical axis. Consequently, the asymmetric component of variation along the apical axis was eliminated from data and subsequent analyses were based entirely on symmetric configurations (Klingenberg et al. 2002). The general Procrustes superimposition (GPA) and the thin-plate spline analysis based on tangent space projections were conducted (BoOKSTEIN 1991; ZelDiTCH et al. 2004).

The principal component analyses (PCA) of partial warps and the uniform component were conducted using the entire set of analysed objects in TpsRelw, ver 1.49. (RohlF 2010b). The scores of the objects on all the non-zero PC axes were used for further analyses. The canonical variates analysis (CVA) of these data was conducted to evaluate discrimination among individual groups in PAST, ver. 2.12. (HAMMER et al. 2001). As there were only 9 objects in the smallest group, we only used the scores on the first 8 PC axes (spanning $97.3 \%$ of the total variation) for this analysis. The group assignments of all the valves were cross-validated by a leave-one-out procedure. Significance of two-group comparisons was evaluated by a set of permutational MANOVA's (ANDERSON 2001) in PAST, ver. 2.12. The Euclidean distance measure was used and the significance values were based on 9999 permutations of the original sets.

\section{Results}

\section{Morphological observations}

Pinnularia divergentissima (GRUNOW in VAN Heurck) Cleve 1895, p. 77, Figs 2-12

Basionym: Navicula divergentissima GRUNOW in VAN Heurck 1880, plate 6, fig. 32.

Synonym: Navicula divergentissima GRUNOW in Cleve \& Möller 1878, slide 186 (nomen nudum), non Pinnularia divergentissima (Grunow) Cleve sensu KRAMMER 1992.

[first-step] Lectotype (designated by KrAMmER 1992: p. 62): coll. Cleve et Möller 1879, slide 186, Grunow Collection in the Naturhistorisches Museum, Vienna, Austria (W).

[second-step] Lectotype (designated here): valve on slide 186, coll. Cleve \& Möller 1879, Grunow Collection in the Naturhistorisches Museum, Vienna, Austria (W), supporting Grunow's published drawing (Grunow in Van Heurck 1880: pl. 6, fig. 32) illustrated here as Fig. 4.

Locality of the lectotype: Fogstuen, Dovre, Norway (coll. Mr. O. Nordstedt). 
Morphological observations (based on the taxon represented by the [second-step] lectotype): Valves strictly lanceolate with weakly convex margins, tapering towards the apices. Ends obtusely rounded, rostrate-capitate. Valve length $27-33 \mu \mathrm{m}$, width (middle) $4.5-5.5 \mu \mathrm{m}$, length-width ratio 5.4-6.6 $(\mathrm{n}=9)$. Axial area very narrow, linear, almost not widening towards the central area. Central area forming a wedge-shaped fascia, lacking shortened striae, never protruding rhombically into the axial area. Raphe branches straight, filiform. Proximal raphe endings very weakly deflected, extending well into the central area with expanded central raphe pores. Terminal raphe fissures shaped like question marks. Transapical striae very strongly radiate near the valve centre, extremely divergent with a sudden change in direction over a halfway distance from the valve centre to the ends, where the striae become strongly convergent with a blunt angle formed between the striae groups where they meet, $12-13 / 10 \mu \mathrm{m}$.

Taxonomical remarks: Since Grunow's original description includes only one single drawing, most likely based on the slide 186 from the Cleve \& Möller Collection at W, the [first-step] lectotypification is accepted (according to art. 9.17 of the McNeILL et al. 2006). Because of the admixture of two species we have decided to lectotypify the Grunow's species with a secondstep lectotype in accordance with McNeILL et al. (2006): art. 9.15. Cleve \& Möller (1878) indicated that Grunow examined slide 186 and in the species list accompanying the slide, Grunow described $N$. divergentissima, unfortunately as a nomen nudum. The specimens observed in slide 186 correspond entirely with the drawing Grunow published in VAN HeURCK (1880) but differ from the specimens showed by KRAMMER $(1992,2000)$ to illustrate $P$. divergentissima. The latter differ clearly in having more rostrate protracted apices, a different central area and less radiate striae (Table 1). For more morphological details on these specimens, see below under $P$. pseudodivergentissima.

\section{Pinnularia pseudodivergentissima sp. nov.,}

Figs 13-21

Synonym: Pinnularia divergentissima (GRUNOw) Cleve sensu Krammer 1992, pl. 12, fig. 1.

Diagnosis: Valvae lineares-lanceolatae marginibus parallelis ad leviter convexis, apicibusque abrupte protractis, rostratis, late rotundatis. Longitudo 22-30 $\mu \mathrm{m}$, latitudo 4.5-6.0 $\mu \mathrm{m}$. Area axialis linearis, recta, graduatim dilatans in aream centralem. Area centralis formans fasciam latam, aliquando asymmetricam. Raphe recta, filiformis terminationibus proximalibus leviter deflexis, extensis in aream centralem. Striae transapicales fortiter radiatae in media parte valvae, magnopere divergentes, valde convergentes in apices, 13-17 in $10 \mu \mathrm{m}$. Lineae speciosae longitudinales nullae.

Holotype: coll. Cleve \& Möller, slide 186 present in the Van Heurck Collection (National Botanic Garden, slide II-7-B2), the valve representing the holotype is illustrated as Fig. 13.

Type locality: Fogstuen, Dovre, Norway

Etymology: the specific epithet refers to the close resemblance with Pinnularia divergentissima s.s. as described by Grunow in VAN HeUrCK 1880.

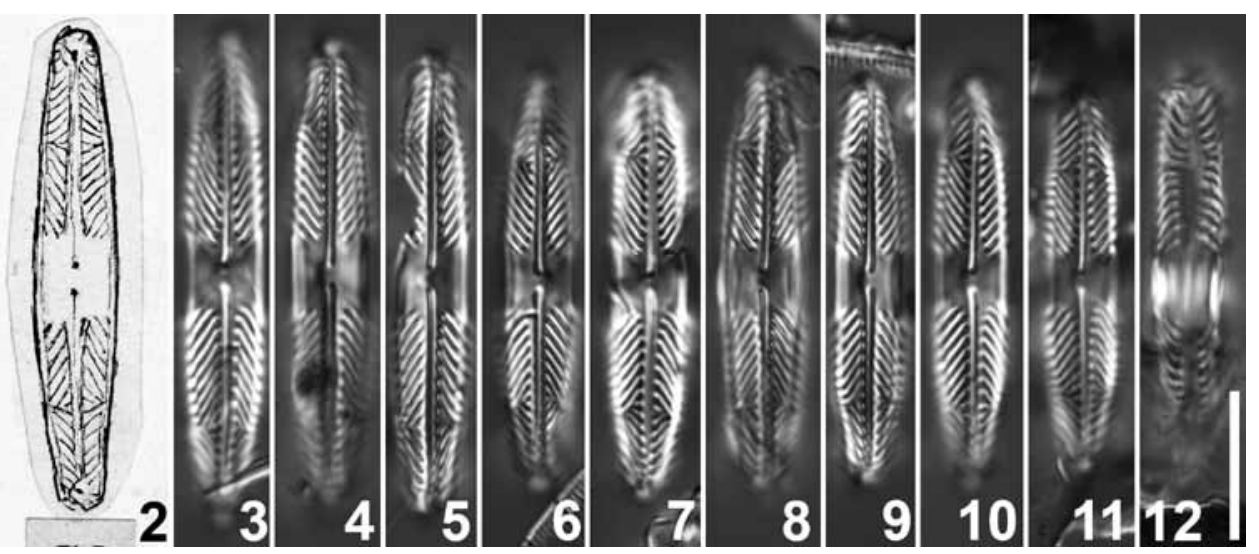

Figs 2-12. Pinnularia divergentissima: (2) original drawing by Grunow in VAN Heurck (1880, plate 6, fig. 32), LM; (3-11) valve views; (12) girdle view. CLEVE \& MöLlER 1879, slide 186 (coll. n II-7-B2), Fogstuen, Dovre, Norway in the Van Heurck Collection in the National Botanic Garden of Belgium (Belgium) (collected by Mr. O. Nordstedt). Scale bar $10 \mu \mathrm{m}$. 


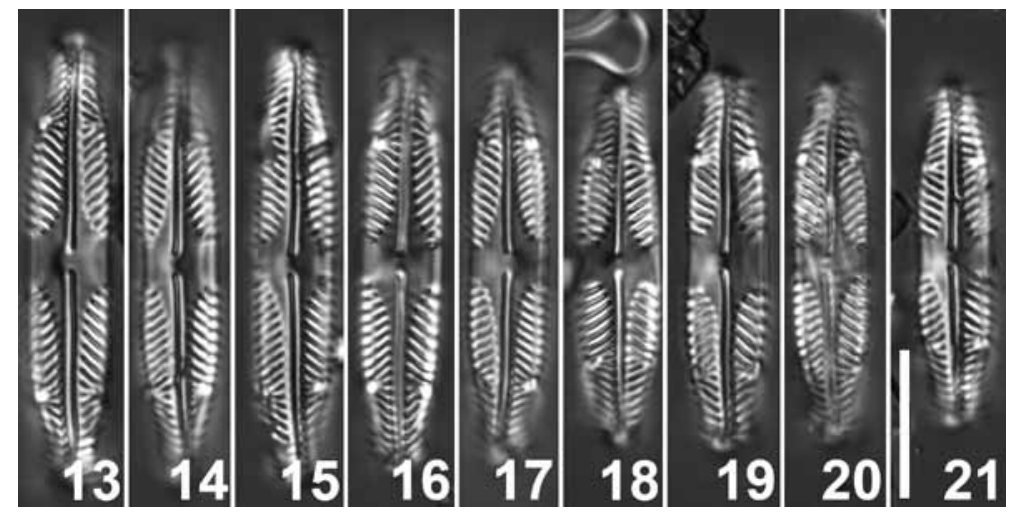

Figs 13-21. Pinnularia pseudodivergentissima. LM. Valve views. Cleve \& Möller 1879, slide 186 (coll. n II-7-B2), Fogstuen, Dovre, Norway in the Van Heurck Collection in the National Botanic Garden of Belgium (Belgium) (collected by Mr. O. Nordstedt). Scale bar $10 \mu \mathrm{m}$.

Morphological observations: Valves linearlanceolate with straight, parallel sometimes weakly convex margins and abruptly protracted, rostrate, broadly rounded apices. Valve length 22-30 $\mu \mathrm{m}$, width (middle) 4.5-6.0 $\mu \mathrm{m}$, lengthwidth ratio 4.8-6.0 $(\mathrm{n}=14)$. Axial area linear, straight, gradually widening towards the central area. Central area forming a broad, occasionally asymmetrical fascia, lacking any shortened striae. Due to the shortening of the transapical striae towards the central area, the latter is protruding rhombically into the axial area. Raphe branches straight or weakly undulating, filiform. Central raphe endings very weakly deflected, extending well into the central area with small, slightly expanded pores. Terminal raphe fissures shaped like question marks. Transapical striae strongly radiate towards the valve centre, extremely divergent with a sudden change in direction over halfway distance from the valve centre to the ends where striae become strongly convergent with an acute angle formed between the striae groups where they meet, $13-17 / 10 \mu \mathrm{m}$. Longitudinal lines absent.

Taxonomical remarks: There are several important morphological differences between $P$. divergentissima and $P$. pseudodivergentissima (Table 1). Pinnularia divergentissima has more convex valve margins resulting in a lanceolate valve outline with rostrate-capitate apices (Figs 3-12) whereas $P$. pseudodivergentissima has narrowly lanceolate valves with mostly parallel to slightly convex margins and clearly protracted rostrate apices (Figs 13-21). The main difference however is formed by the striation pattern. $P$. divergentissima has very strongly radiate striae near the central area, rarely shortened reaching therefore almost always to the axial area. On the contrary, P. pseudodivergentissima shows radiate striae near the central area, gradually shortening towards the fascia showing a rhombical central area protruding into the axial area. Pinnularia divergentissima shows a very obtuse angle between the radiate striae and the convergent striae whereas in $P$. pseudodivergentissima, this angle is more acute. Finally, $P$. divergentissima has a lower stria density with only $12-13$ striae in $10 \mu \mathrm{m}$ whereas P. pseudodivergentissima has 13-17 striae in 10 $\mu \mathrm{m}$. Based on these morphological differences, a separation of both species is justified.

\section{Pinnularia fottii J.Bílý et Marvan 1959,}

\section{Figs 22-35}

Type locality: slide 575B IOK, Věčný déšt', Vysoké Tatry, Slovakia

Morphological observations: Valves linear to narrowly lanceolate with parallel margins and broadly rounded, rostrate apices. Valve length 28 $35.5 \mu \mathrm{m}$, width $4.5-6.0 \mu \mathrm{m}$, length-width ratio 4.6-7.2 $(n=60)$. Axial area narrow, linear, only slightly widening towards the central area. Central area forming a large, wedge-shaped fascia. Striae bordering the axial area near the fascia clearly shortened. Raphe branches straight to weakly curved, filiform with deflected elongated pore-like proximal endings and "question marks"-shaped terminal fissures. Transapical striae strongly radiate near the central area, extremely divergent with a sudden change in direction over halfway from the valve centre to the ends where striae become strongly convergent with a rather acute angle formed between the striae groups where 


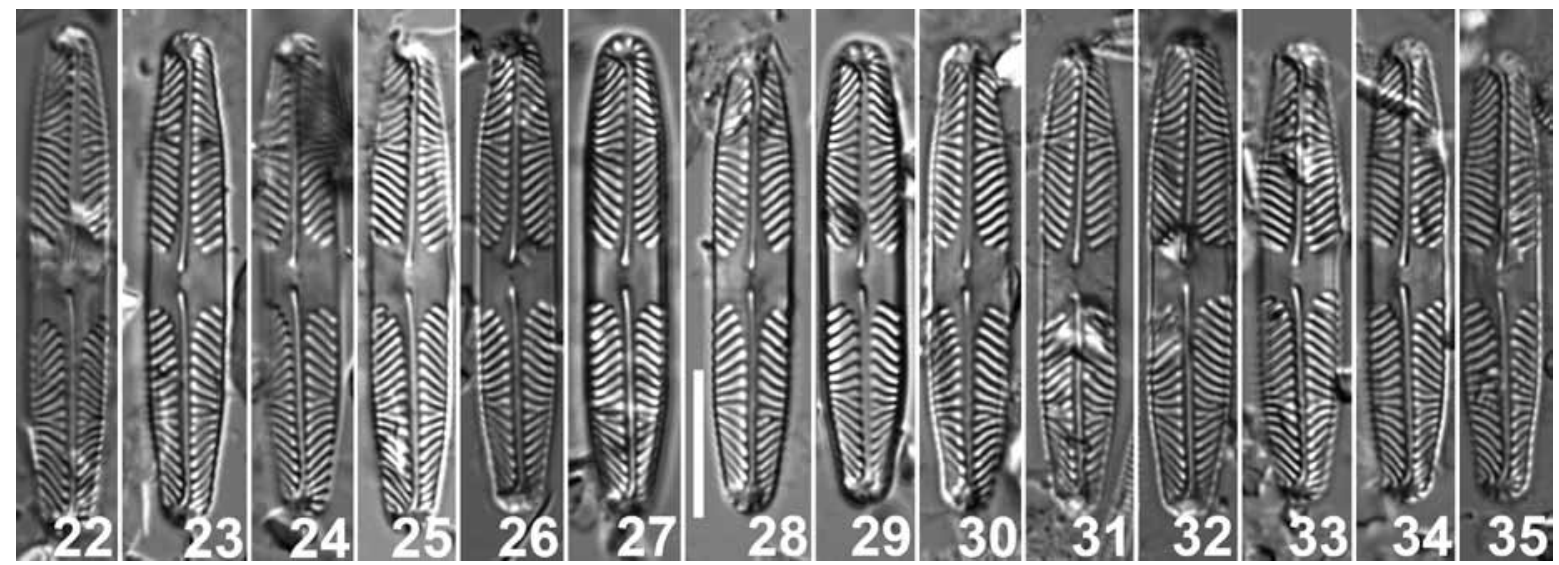

Figs 22-35. Pinnularia fottii. LM. Valve views. Slide 575B IOK, Věčný déšt', Vysoké Tatry, Slovakia in the herbarium of the Botanical Institute of the Masaryk University, Brno (Czech Republic). Scale bar $10 \mu \mathrm{m}$.

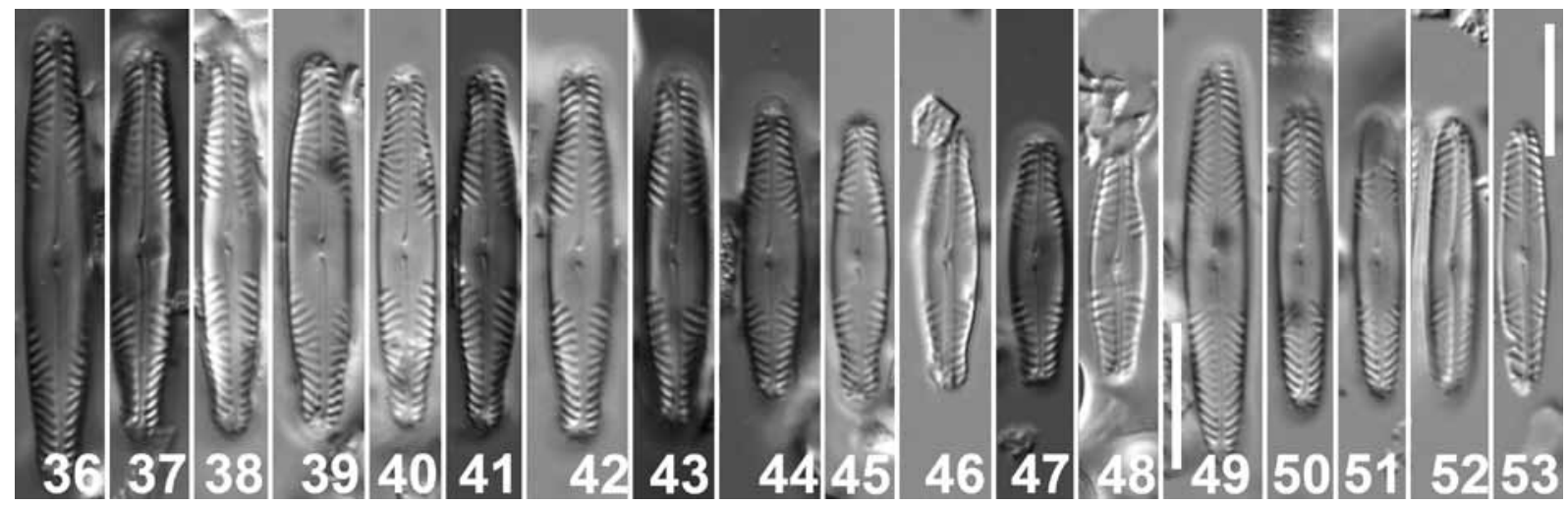

Figs 36-48. Pinnularia martinii. LM. Valve views. Figs 49-53. Pinnularia martinii f. elliptica. LM. Valve views. Slide 4165 S. Vincente, Brandungshöhlen von Ramuncho, Krasske Collection, Kassel (Germany). Scale bar $10 \mu \mathrm{m}$.

they meet, $11-15$ in $10 \mu \mathrm{m}$.

Taxonomical remarks: Pinnularia fottii was considered by KRAMMER $(1992,2000)$ to be a younger synonym of $P$. divergentissima. Although belonging to the complex of $P$. divergentissima and showing similar valve dimensions (Table 1), the morphological comparison showed that the species differs morphologically from both $P$. divergentissima and $P$. pseudodivergentissima, as observed in the Cleve \& Möller 186-slide. The former has more strongly radiate striae shifting with an obtuse angle to the quite convergent striae near the apices. The axial area in $P$. pseudodivergentissima is widening more distinctly towards the central area forming a much larger rhombically widened central area than in $P$. fottii where the axial area widens only close to the central area. Moreover, the valve outline of $P$. fottii shows more parallel margins with broadly rostrate, not suddenly offset rounded apices whereas $P$. pseudodivergentissima has more clearly offset rostrate-capitate apices and $P$. divergentissima shows a more lanceolate outline with more capitate-rostrate apices.

Two other Pinnularia species, P. grudeensis Foged and $P$. krammeri Metzeltin in LangeBertalot et Metzeltin, described from Norway (Foged 1970) and Finland (Lange-Bertalot \& Metzeltin 1996) show a similar valve outline to $P$. fottii but can be distinguished based on their valve dimensions, having wider valves $(6.7-7.8 \mu \mathrm{m}$ in P. krammeri and 9-10 $\mu \mathrm{m}$ for P. grudeensis).

\section{Pinnularia martinii Krasske 1939, Figs 36-48} (49-53?)

Lectotype (designated by Thomas Lauser in Krammer 1992, p. 63): preparation D III 3, Krasske Collection, Kassel (Germany).

Type locality: slide 4165 S. Vincente, Brandungshöhlen von Ramuncho (Chile)

Synonyms: Pinnularia divergentissima var. martinii Krasske sensu Krammer (1992), P. divergentissima 


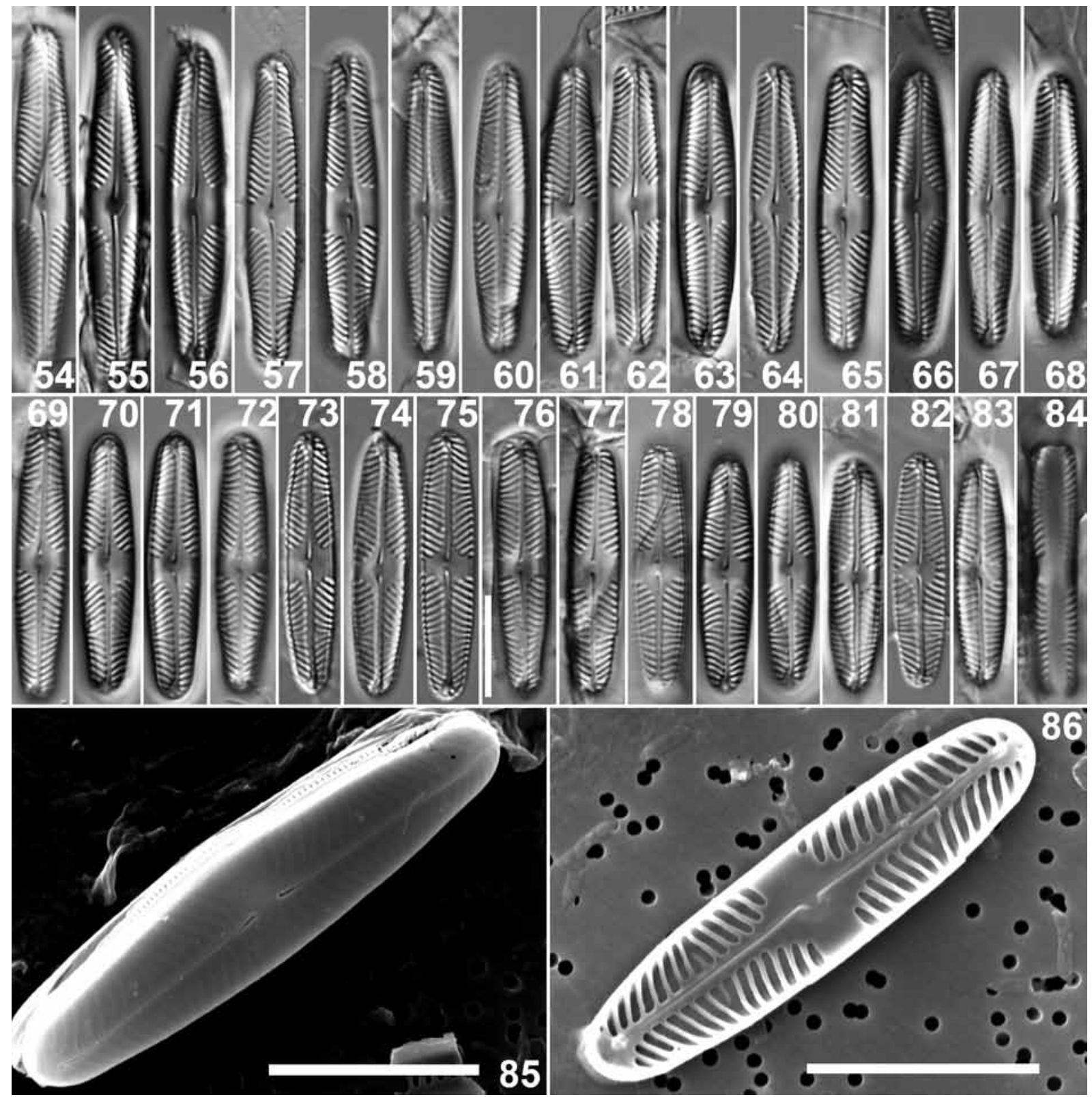

Figs 54-86. Pinnularia lindanedbalovae: (54-83) LM Valve views; (84) LM. girdle view; (85) SEM external view; (86) SEM internal view. Scale bar $10 \mu \mathrm{m}$.

var. subrostrata CLEVE sensu KRAMMER (2000).

Morphological observations: Valves narrowly elliptical to narrowly lanceolate with convex margins and protracted, rostrate-capitate to even capitate apices. Valve length $16.5-32.0 \mu \mathrm{m}$, width 3.5-6.0 $\mu \mathrm{m}$, length-width ratio 4.6-7.2. Axial area narrow, gradually widening towards the central area. Central area forming a large rectangular to wedge-shaped fascia due to irregular shortening of striae delimiting the central area. Raphe branches weakly curved, filiform with slightly deflected, expanded, pore-like proximal endings and "question marks"-shaped terminal fissures.
Transapical striae strongly radiate near the valve centre, extremely divergent with a sudden shift in direction halfway between the valve centre and the apices where striae become strongly convergent with an acute angle formed between the striae groups where they meet, $11-16$ in $10 \mu \mathrm{m}$.

Taxonomical remarks: KRAMMER (1992) stated that $P$. martinii should be combined with $P$. divergentissima (sensu KRAMMER) as a variety and proposed the new combination $P$. divergentissima var. martinii, although a formal justification for this new combination was never presented and Lange-Bertalot et al. (1996) discussed 

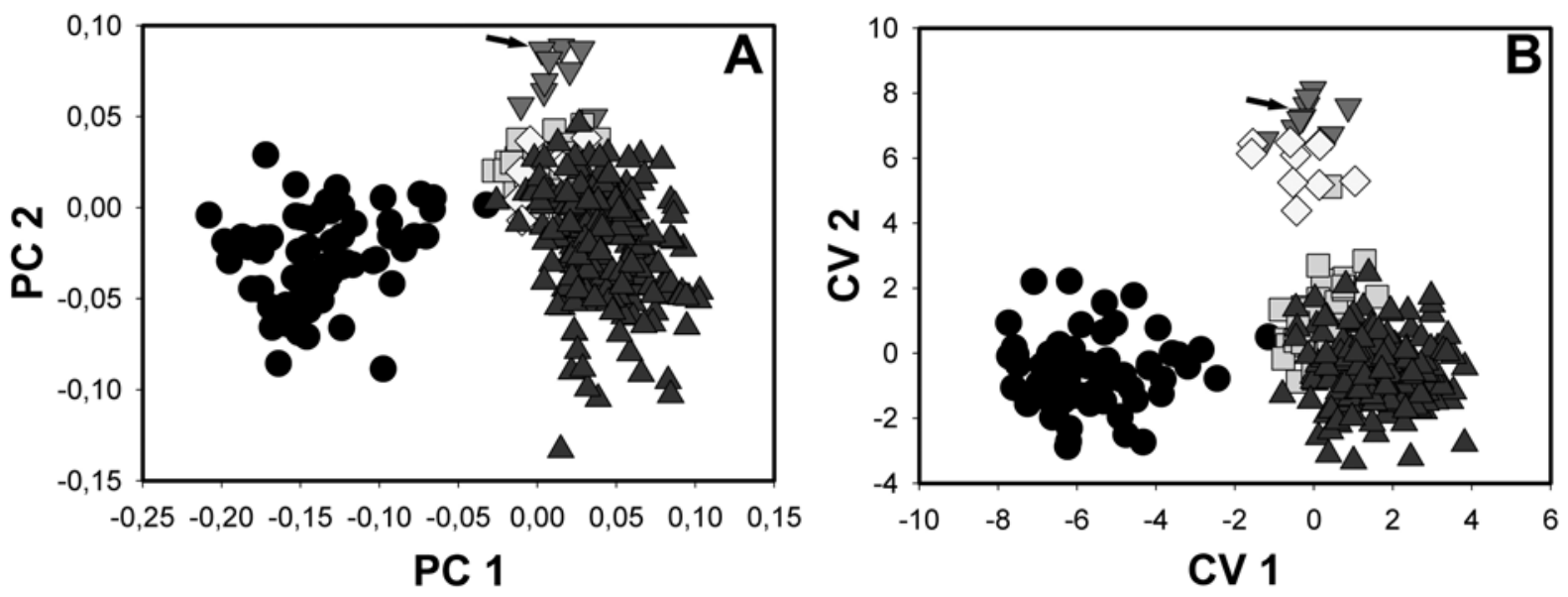

Fig. 87. Ordination plots representing first two axes of PCA (A), and first two axes of CVA (B). The arrows indicate position of the Grunow's original drawing (Grunow in VAN Heurck 1880, plate 6, fig. 32) in the ordination spaces. Black circles: $P$. martinii; gray triangles: P. lindanedbalovae; light gray squares: . fottii; white diamonds: P. pseudodivergentissima; dark gray inverse triangles: $P$. divergentissima.

Krammer's taxonomic view as unresolved with respect to biogeographical data. In 2000, KRAMMER considered $P$. divergentissima var. martinii as a younger synonym of $P$. divergentissima var. subrostrata Cleve 1895 [and not Cleve-Euler 1898 as written in KRAMMER (2000)]. KULIKOVSKIY et al. (2010) validated the (invalid) raise to species level of $P$. subrostrata (Cleve) Cleve-Euler proposed by CLEVE-EULER in 1955.

However, based on the analysis of the type material, KRAMMER's statement on the synonymy of both taxa should be contradicted. The central area in P. martinii forms a larger fascia with the proximal raphe endings extending much farther beyond the striae delimiting the fascia, contrary to $P$. divergentissima var. subrostrata that has only a small fascia, with the proximal raphe endings extending not far beyond the delimiting central striae.

In the same slide, KRASSKE (1939) separated the specimens lacking any protracted apices as $P$. martinii f. elliptica (Figs 49-53). Most of these elliptica-forms are smaller than $20 \mu \mathrm{m}$, although some larger valves (up to $28 \mu \mathrm{m}$ ) were found, overlapping with the smaller range of the rostratecapitate $P$. martinii. Therefore, valve outline seems to be the only difference with $P$. martinii. Whether these forms should thus be considered as a separate species, a form of $P$. martinii or a synonym of $P$. divergentissima var. ardnamurchan KRAMMER is still unclear. The latter was described by KRAMMER in 2000 for all divergentissima-like specimens lacking rostrate or capitate apices. KRAMMER (2000) indicated that $P$. martinii f. elliptica is similar to this new variety.

Pinnularia lindanedbalovae VAN DE VIJVER et Moravcová sp. nov., Figs 54-86

Diagnosis: Valvae anguste lanceolatae marginibus leviter convexis, apicibusque protractis, subcapitatis ad subrostratis, obtuse rotundatis. Longitudo 18-42

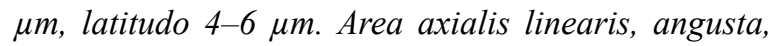
leviter dilatans in aream centralem. Area centralis formans fasciam latam, aliquando asymmetricam. In speciminibus minoribus, fascia carens. Raphe leviter curvata ad leviter undulata, filiformis terminationibus proximalibus expansis, extensis in aream centralem. Striae transapicales distincte radiatae in media parte valvae, divergentes, valde convergentes in apices, 1318 in $10 \mu \mathrm{m}$. Lineae speciosae longitudinales nullae.

Holotype: BR-4240 (National Botanic Garden, Meise, Belgium), the valve representing the holotype is illustrated as Fig. 56.

Isotypes: PLP-188 (University of Antwerp, Belgium), BRM-ZUH8/50 (Hustedt Collection, Bremerhaven, Germany)

Type locality: Champs des Albatros, sample N3-10, Ile de la Possession, Crozet Archipelago, southern Indian Ocean (coll. B. Van de Vijver, coll. date: $12 / 01 / 2005)$

Etymology: The species is named after our colleague Dr. Linda Nedbalová (Charles University in Prague, Czech Republic).

Morphological observations: Valves narrowly lanceolate with weakly convex margins. Smaller specimens with more elliptic-lanceolate outline and clearly convex margins (Figs 81-83). Valve 
apices protracted, subcapitate to subrostrate, obtusely rounded. Smaller specimens sometimes with broadly rounded, non protracted apices (Figs 81-83). Valve length $18-42 \mu \mathrm{m}$, valve width 4-6 $\mu \mathrm{m}$, length-width ratio 3.4-7.0. Axial area narrow, linear, only near the central area clearly widened. Central area forming a broad, sometimes asymmetrical fascia. Smaller specimens sometimes lacking a fascia due to the presence of gradually shortened striae. Raphe branches weakly curved to even slightly undulated, filiform with enlarged, elongated drop-like proximal raphe endings, extending into the central area. Distal raphe fissures "question mark"-shaped. Transapical striae distinctly radiate near the valve centre, divergent with a sudden change in direction over halfway between the valve centre and valve apices where striae become strongly convergent with an almost straight angle formed between the striae groups where they meet, 13$18 / 10 \mu \mathrm{m}$. Striae composed of alveoli with 3-4 series of small rounded pores (Fig 85). Internally, proximal raphe endings unilaterally hooked (Fig 86).

Taxonomical remarks: Pinnularia lindanedbalovae clearly belongs to the complex of species around $P$. divergentissima based on the presence of the clear shift in stria direction. In several papers dealing with the non-marine diatom flora of the islands, the species was identified as $P$. divergentissima (VAN DE VIJVER \& BEYENS 1999; VAN DE VIJVER et al. 2001, 2002, 2004, 2008). However, both species differ in several ways (Table 1). Smaller valves of $P$. lindanedbalovae often lack a stauros with gradually shortened striae bordering the central area whereas this was never observed in $P$. divergentissima. Moreover, the striae orientation in $P$. divergentissima is much more radiate than in $P$. lindanedbalovae. The valve outline of $P$. lindanedbalovae usually shows a clear constriction before the valve apices, which was never observed in $P$. divergentissima. The axial area in $P$. pseudodivergentissima widens more clearly towards the central area whereas in P. lindanedbalovae, this widening is only present close to the central area. The absence of a fascia was never observed in P. pseudodivergentissima. Pinnularia fottii has usually parallel margins lacking a clear constriction before the apices. Usually, the valve margins are only near the apices clearly tapering towards the bluntly rounded apices whereas in P. lindanedbalovae, the apices normally widen again slightly. A broad fascia was always observed in $P$. fottii contrary to $P$. lindanedbalovae, that lacks a fascia in a large part of its range.

Ecology and distribution: Pinnularia lindanedbalovae was observed (but always reported as $P$. divergentissima) on several islands in the southern Indian Ocean: Prince Edward Islands (VAN DE ViJver et al. 2008), Crozet Archipelago (VAN DE VIJver et al. 2002), Iles Kerguelen (VAN DE VIJVER et al. 2001) and Heard Island (VAN DE VIJVER et al. 2004). On Ile Amsterdam, the species was observed in small numbers (VAN DE VIJVER et al. 2012). Whether the species is also present in the southern Atlantic Ocean remains unclear due to confusion with other Pinnularia taxa.

The type population was observed in the disturbed very wet soil near an occupied albatross nest characterized by an acid $\mathrm{pH}$ (5.7), a high specific conductance value $\left( \pm 1100 \mu \mathrm{S} . \mathrm{cm}^{-1}\right)$ and high nutrient values (VINCKE et al. 2007; Moravcová et al. 2010). On Ile de la Possession (Crozet Archipelago), the species was in general mostly found in wet to very wet $(60-85 \%$ of relative moisture) and acid $(\mathrm{pH}<6)$ soils with higher specific conductance values $\left(>600 \mu \mathrm{S} . \mathrm{cm}^{-1}\right)$ while in mosses and aquatic samples, the species was only rarely observed (VAN DE VIJVER et al. 2002). On the other islands, smaller populations were found usually in terrestrial mosses impacted by sea-spray or biotic influences.

\section{Geometric morphometrics}

The ordination plot representing the first and second PC axes spanned $79.3 \%$ of the total variation in the morphometric data (Fig. 87A). The first axis $(57.4 \%$ of the variation) clearly separated $P$. martinii from the other taxa. Conversely, the second axis (21.9\%) illustrated the differences between $P$. divergentissima (including Grunow's type drawing) and all the other taxa. The first two axes of the highly significant CVA (Wilk's $\lambda=0.018, p<0.0001$ ) clearly separated $P$. martinii and the pair $P$. divergentissima/P. pseudodivergentissima from the other taxa (Fig. 87B). However, the mean shape differences were highly significant among all the species pairs. The Bonferroni-corrected $p$-values were 0.001 in all the two-group permutational MANOVA comparisons. The cross-validation analyses of the canonical discriminant function revealed that $95.2 \%$ of the valves were correctly clasified 
Table 1. Table of comparison of the species belonging to the Pinnularia divergentissima complex.

\begin{tabular}{|c|c|c|c|c|c|}
\hline & divergentissima & $\begin{array}{l}\text { pseudo-divergen- } \\
\text { tissima }\end{array}$ & martinii & fotii & linda-nedbalovae \\
\hline & $\begin{array}{l}\text { VAN HEURCK } \\
(1880)\end{array}$ & this study & KRASSKE (1939) & $\begin{array}{l}\text { BílÝ \& MARVAN } \\
\text { (1959) }\end{array}$ & this study \\
\hline Length $(\mu \mathrm{m})$ & $27-33$ & $22-30$ & $8-30$ & $28-35.5$ & $18-35(43)$ \\
\hline Width $(\mu \mathrm{m})$ & $4.5-5.5$ & $4.5-6.0$ & $2.5-5.0$ & $4.5-6.0$ & $4.0-6.7$ \\
\hline $\mathrm{L} / \mathrm{W}$ ratio & $5.4-6.6$ & $4.8-6.0$ & 4.7 & $4.6-7.2$ & $3.4-7.1$ \\
\hline $\begin{array}{l}\text { number of striae } \\
\text { (in } 10 \mu \mathrm{m} \text { ) }\end{array}$ & $12-13$ & $13-17$ & $12-13$ & $11-15$ & $13-18$ \\
\hline outline & lanceolate & linear-lanceolate & $\begin{array}{l}\text { elliptical, linear to } \\
\text { lanceolate }\end{array}$ & $\begin{array}{l}\text { linear to narrowly } \\
\text { lanceolate }\end{array}$ & lanceolate \\
\hline apices & not offset, rounded & rostrate & $\begin{array}{l}\text { broadly rounded to } \\
\text { capitate }\end{array}$ & $\begin{array}{l}\text { broadly rounded, } \\
\text { rostrate }\end{array}$ & $\begin{array}{l}\text { broadly } \\
\text { rounded,rostrate } \\
\text { to subcapitate in } \\
\text { large valves }\end{array}$ \\
\hline shift in striae & clearly present & clearly present & clearly present & clearly present & $\begin{array}{l}\text { present, absent in } \\
\text { smaller valves }\end{array}$ \\
\hline $\begin{array}{l}\text { transition cen- } \\
\text { tral-axial area }\end{array}$ & $\begin{array}{l}\text { narrow, very } \\
\text { abruptly, no del- } \\
\text { toid-shape }\end{array}$ & $\begin{array}{l}\text { broad deltoid-- } \\
\text { shaped }\end{array}$ & $\begin{array}{l}\text { narrow deltoid-- } \\
\text { shaped }\end{array}$ & $\begin{array}{l}\text { narrow deltoid-- } \\
\text { shaped }\end{array}$ & $\begin{array}{l}\text { narrow deltoid-- } \\
\text { shaped }\end{array}$ \\
\hline \multirow[t]{2}{*}{ ecology } & $\begin{array}{l}\text { acid, oligotrophic, } \\
\text { electrolyte-poor* }\end{array}$ & $\begin{array}{l}\text { acid, oligotrophic, } \\
\text { electrolyte-poor* }\end{array}$ & $\begin{array}{l}\text { soils in coastal } \\
\text { areas close to sea } \\
\text { spray zone }\end{array}$ & - & $\begin{array}{l}\text { soils, aerophilic, } \\
\text { coastal areas }\end{array}$ \\
\hline & $\begin{array}{l}\text { *derived from } \\
\text { dominating diatom } \\
\text { composition }\end{array}$ & & & & \\
\hline
\end{tabular}

into their species groups. The highest error rates concerned the pair of $P$. lindanedbalovae and $P$. fottii. In total, $5.6 \%$ of valves that were a priori assigned as $P$. lindanedbalovae were classified to the $P$. fottii group, and, conversely, $5.1 \%$ of valves a priori assigned as $P$. fottii were classified to $P$. lindanedbalovae (Table 2).

\section{Discussion}

Geometric morphometrics illustrated that differences in valve shape among all the taxa were significant. Grunow's type drawing was firmly nested within other frustules from the Cleve \& Möller 186 slide that were assigned to the true $P$. divergentissima s.s. on the basis of microscopic analysis. Conversely, frustules assigned as $P$. pseudodivergentissima were unambiguously separated from $P$. divergentissima by the crossvalidation analyses. Geometric morphometric comparison of original type drawings or specimens from type slides with modern populations has already been used in diatom taxonomy (FRÁNKOVÁ et al. 2009). This study further illustrated that it can be highly useful in supporting (or disproving) the qualitative microscopic analyses and subsequent taxonomic conclusions. We should note that our analyses only concerned data from valves symmetrised along the apical axis. Neither the obvious left-right asymmetry of valves (indicated e.g. by central raphe poles), nor possible vertical asymmetry of valves were taken into account. The material analysed by geometric morphometrics in 


\begin{tabular}{|c|c|c|c|c|c|c|}
\hline & acoricola & krammeri & obscura & diversa & osoresanensis & grudeensis \\
\hline & Hustedt (1935) & $\begin{array}{l}\text { LANGE-BERTALOT } \\
\text { \& METZELTIN } \\
(1996)\end{array}$ & $\begin{array}{l}\text { KRASSKE } \\
(1932)\end{array}$ & ØSTRUP (1901) & $\begin{array}{l}\text { FUKUSHIMA et } \\
\text { al. }(2002)\end{array}$ & Foged (1970) \\
\hline Length $(\mu \mathrm{m})$ & $8-35$ & $26-45$ & $12-34$ & $23-39$ & $7-29$ & $35-40$ \\
\hline Width $(\mu \mathrm{m})$ & $3-6$ & $6.7-7.8$ & $3.0-5.4$ & $5-6$ & $4.0-6.0$ & $9-10$ \\
\hline $\mathrm{L} / \mathrm{W}$ ratio & $2.4-6.5$ & $3.7-5.8$ & $3.7-6.0$ & $5.8-7.0$ & $3.0-5.1$ & 3.7 \\
\hline $\begin{array}{l}\text { number of } \\
\text { striae (in } 10 \\
\mu \mathrm{m})\end{array}$ & $13-16$ & $11-13$ & $10-13$ & $10-12$ & $15-19$ & 12 \\
\hline outline & $\begin{array}{l}\text { elliptic-lanceo- } \\
\text { late to lanceolate, } \\
\text { semirhomboidal }\end{array}$ & $\begin{array}{l}\text { linear to linear- } \\
\text { elliptical }\end{array}$ & linear-elliptical & $\begin{array}{l}\text { rhombic-lan- } \\
\text { ceolate }\end{array}$ & $\begin{array}{l}\text { linear to lan- } \\
\text { ceolate }\end{array}$ & almost linear \\
\hline apices & $\begin{array}{l}\text { small cuneiform, } \\
\text { rounded to cune- } \\
\text { ate }\end{array}$ & $\begin{array}{l}\text { broadly wedge-- } \\
\text { shaped, rounded }\end{array}$ & $\begin{array}{l}\text { weakly rostrate } \\
\text { or cuneiform, } \\
\text { not offset } \\
\text { and broadly } \\
\text { rounded }\end{array}$ & $\begin{array}{l}\text { not offset, } \\
\text { obtusely cune- } \\
\text { ate or weakly } \\
\text { capitate }\end{array}$ & $\begin{array}{l}\text { cuneiform to } \\
\text { rounded }\end{array}$ & $\begin{array}{l}\text { broadly } \\
\text { rounded }\end{array}$ \\
\hline shift in striae & clearly present & clearly present & weakly present & clearly present & $\begin{array}{l}\text { present to al- } \\
\text { most absent in } \\
\text { smaller valves }\end{array}$ & $\begin{array}{l}\text { clearly pres- } \\
\text { ent }\end{array}$ \\
\hline $\begin{array}{l}\text { transition } \\
\text { central-axial } \\
\text { area }\end{array}$ & $\begin{array}{l}\text { broad deltoid-- } \\
\text { shaped }\end{array}$ & $\begin{array}{l}\text { narrow deltoid-- } \\
\text { shaped }\end{array}$ & $\begin{array}{l}\text { narrow del- } \\
\text { toid-shaped }\end{array}$ & $\begin{array}{l}\text { narrow del- } \\
\text { toid-shaped }\end{array}$ & $\begin{array}{l}\text { broad deltoid-- } \\
\text { shaped }\end{array}$ & $\begin{array}{l}\text { broad del- } \\
\text { toid-shaped }\end{array}$ \\
\hline ecology & $\begin{array}{l}\text { oligosaprobic, } \\
\text { electrolyte-poor } \\
\text { waters }\end{array}$ & $\begin{array}{l}\text { oligotrophic, } \\
\text { electrolyte-poor } \\
\text { waters }\end{array}$ & $\begin{array}{l}\text { aerophillic, } \\
\text { moist mosses, } \\
\text { wet rocks }\end{array}$ & $\begin{array}{l}\text { oligotrophic, } \\
\text { oxygen rich, } \\
\text { electrolyte } \\
\text { poor moorland } \\
\text { waters }\end{array}$ & $\begin{array}{l}\text { inorganic, } \\
\text { strongly acid } \\
\text { waters }\end{array}$ & $\begin{array}{l}\text { postglacial } \\
\text { kieselguhr }\end{array}$ \\
\hline
\end{tabular}

this study was indeed too scarce (especially in $P$. divergentissima and $P$. pseudodivergentissima) to allow meaningful application of methods decomposing symmetric and asymmetric parts of variation (SAVRIAMA et al. 2010; SaVRiama \& KLingenberg 2011). However, future morphometric studies of the genus Pinnularia should definitely also encompass the symmetry/ asymmetry analyses that may help in defining quantitative morphological differences among species.

Krammer $(1992,2000)$ lumped several Pinnularia taxa showing comparable morphological features under $P$. divergentissima, considerably broadening that way not only the morphological variability of the latter but also its worldwide geographical distribution. However, taxonomic research on other diatom complexes/species has indicated that both species drift, i.e. the continuous broadening of the original species description, and force fitting (TYLER 1996) as a result of the use of European or North American identification guides in other continents, are the two main reasons for underestimating the diatom diversity in remote areas (SABBE et al. 2003; VAN De ViJVer et al. 2005; VAN De ViJver \& Mataloni 2008; Zidarova et al. 2010). This not only led to misinterpretations of the biodiversity of these areas but more important, has major implications on the biogeography of diatom species, creating a large set of cosmopolitan species showing a broad morphological variability.

Although the different taxa from the $P$. divergentissima complex including the newly described species can only be considered to be 'morphospecies' as data on their genetic structure is currently lacking, several recent 
Table 2. The cross-validation matrix of the canonical variates analysis. Rows indicate the given groups and columns indicate the groups predicted by the discriminant function, respectively. Numbers correspond to valves classified to individual taxa.

\begin{tabular}{llllll}
\hline & P. martinii & $\begin{array}{l}\text { P. divergen- } \\
\text { tissima }\end{array}$ & P. fottii & $\begin{array}{l}\text { P. pseudodivergen- } \\
\text { tissima }\end{array}$ & $\begin{array}{l}\text { P. lindanedba- } \\
\text { lovae }\end{array}$ \\
\hline P. martinii & 63 & 0 & 1 & 0 & 0 \\
P. divergentissima & 0 & 9 & 0 & 0 & 0 \\
P. fottii & 0 & 1 & 36 & 0 & 2 \\
P. pseudodivergentissima & 0 & 0 & 0 & 10 & 0 \\
P. lindanedbalovae & 0 & 0 & 12 & 0 & 201 \\
\hline
\end{tabular}

studies on other diatom taxa such as Cyclotella meneghiniana KüTz., Sellaphora pupula (Küтz.) MERESCHK. or Pseudonitzschia, indicated that there is a widespread occurrence of (semi)cryptic diversity in diatoms (BehnKe et al. 2004; MANN et al. 2004, 2008; Bezsteri et al. 2005; PoulíčKovÁ et al. 2010; VAN ElsLander et al. 2009). In most cases, the results of the morphological analyses were confirmed by molecular data. The distinction of the different taxa of the $P$. divergentissima complex, even based on subtle morphological differences, can therefore be considered highly probable.

\section{Acknowledgements}

Sampling on Crozet has been made possible thanks to the logistic and financial support of the French Polar Institute-Paul-Emile Victor in the framework of the terrestrial program 136 (Ir. Marc Lebouvier \& Dr. Yves Frenot). Pierre Compère is thanked for his valuable taxonomical and nomenclatural comments. This research was financially supported by the Grant Agency of the Charles University in Prague (GAUK 139910) and partly by the project MSMT $\mathrm{N}^{\circ}$ 0021620828. Adéla Moravcová benefitted from an ERASMUS travel grant during her research stay in the National Botanic Garden of Belgium. Dr. Anton Igersheim, curator of the Cryptogam Collection at the Naturhistorisches Museum in Vienna is acknowledged for borrowing us the type slide of $P$. divergentissima.

\section{References}

Anderson, M.J. (2001): A new method for nonparametric multivariate analysis of variance. Austral Ecology 26: 32-46.

BehnKe, A.; Friedl, T.; Chepurnov, V.A. \& Mann, D.G. (2004): Reproductive compatibility and rDNA sequence analyses in the Sellaphora pupula species complex (Bacillariophyta). - Journal of
Phycology 40: 193-208.

Beszteri, B.; Ács, E. \& Medlin, L.K. (2005): Ribosomal DNA sequence variation among sympatric strains of the Cyclotella meneghiniana complex (Bacillariophyceae) reveals cryptic diversity. Protist 156: 317-333.

Bílý, J. \& Marvan, P. (1959): Diatomeen der überrieselten Felsen 'Večný Dážd" in der Hohen Tatra (ČSR). - Sborník Prác o Tatranskom Národnom Parku 3: 57-73.

Bookstein, F.L. (1991): Morphometric tools for landmark data: geometry and biology. - 435 pp., Cambridge University Press, Cambridge.

Cleve, P.T. \& Möller, I.D. (1878): Diatoms. Uppsala, Esaias Edquists Boktryckeri.

Cleve, P.T. (1895): Synopsis of the naviculoid diatoms. Part II. - Konglige Svenska VetenskapsAkademiens Handlingar 27: 1-219.

Cleve-Euler, A. (1955): Die Diatomeen von Schweden und Finnland. Teil IV. Biraphideae 2. -Kungliga Svenska Vetenskapsakademiens Handlingar 5: 1-232.

Foged, N. (1970): The diatomaceous flora in a postglacial kieselguhr deposit in southwestern Norway. - Beihefte zur Nova Hedwigia 31: 169-202.

Fránková, M.; PoulíčKová, A.; Neustupa, J.; Pichrtová, M. \& Marvan, P. (2009): Geometric morphometrics - a sensitive method for diatom morphospecies distinguishing: a case study on the sympatric populations of Reimeria sinuata and Gomphonema tergestinum (Bacillariophyceae) from the River Bečva, Czech Republic. - Nova Hedwigia 88: 81-95.

Fukushima, H.; Yoshitake, S. \& Ko-Bayashi, T. (2002): Three new diatoms Pinnularia from acid waters in Japan. - Diatom 18: 1-12.

Hammer, Ø.; Harper, D.A.T. \& Ryan, P.D. (2001): PAST: Paleontological statistics software package for education and data analysis. Palaeontologia Electronica 4: 1-9.

Hendey, N.I. (1964): An introductory account of the smaller algae of British coastal waters. Part V. 
Bacillariophyceae (Diatoms). - London: her Majesty's Stationery Office, 317 pp. +44 plates.

Hustedt, F. (1935): Die fossile Diatomeenflora in den Ablagerungen des Tobasees auf Sumatra. Tropische Binnengewässer, Band VI. - Archiv für Hydrobiologie, Supplement 14: 143-192.

Klingenberg, C.P.; Barluenga, M. \& Meyer, A. (2002): Shape analysis of symmetric structures: quantifying variation among individuals and asymmetry. - Evolution 56: 1909-1920.

Krammer, K. (1992): Pinnularia, eine Monographie der Europäischen Taxa. - Bibliotheca Diatomologica 26: 1-353.

Krammer, K. (2000): The genus Pinnularia. - In: LANGE-Bertalot, H. (ed.): Diatoms of Europe. Diatoms of the European Inland waters and comparable habitats. Vol. 1. - 703 pp., A.R.G. Gantner Verlag, K.G., Ruggell.

Krasske, G. (1932): Beiträge zur Kenntnis der Diatomeenflora der Alpen. - Hedwigia 72: 92-135.

KRASSKe, G. (1939): Zur Kieselalgenflora Südchiles. Archiv für Hydrobiologie 35: 349-468.

Kulikovskiy, M.S.; Lange-Bertalot, H.; Witkowski, A.; Dorofeyuk, N.I. \& Genkal, S.I. (2010): Diatom assemblages from Sphagnum bogs of the world. I. Nur bog in northern Mongolia. Bibliotheca Diatomologica 55: 1-326.

Lange-Bertalot, H.; Külbs, K.; Lauser, T.; Nörpel-Schempr, M. \& Willmann, M. (1996): Diatom taxa introduced by Georg Krasske. Documentation and revision. Dokumentation und Revision der von Georg Krasske beschriebenen Diatomeen-Taxa. Iconographia Diatomologica 3: 1-358.

Lange-Bertalot, H. \& Metzeltin, D. (1996): Oligotrophie-Indikatoren. $800 \quad$ Taxa repräsentativ für drei diverse Seen-Typen. Iconographia Diatomologica 2: 1-390.

Mann, D.G.; McDonald, S.M.; Bayer, M.M.; Droop, S.J.M.; Chepurnov, V.A.; LoKe, R.E.; Ciobanu, A. \& Hans Du Buf, J.M. (2004): The Sellaphora pupula species complex (Bacillariophyceae): morphometric analysis, ultrastructure and mating data provide evidence for five new species. - Phycologia 43: 459-482.

Luís, A.T.; Novais, M.H.; VAn DE ViJver, B.; Almeida, S.F.P.; Ferreira da Silva, E.A.; Hoffmann, L. \& Ector, L. (2012): Pinnularia aljustrelica sp. nov. (Bacillariophyceae), a new diatom species found in acidic waters in the Aljustrel mining area (Portugal) and further observations on the taxonomy and ecology of $P$. acidophila Hofmann et Krammer and P. acoricola Hustedt. - Fottea 12: 27-40.

Mann, D.G.; Thomas, S.J. \& Evans, K.M. (2008): Revision of the diatom genus Sellaphora: a first account of the larger species in the British Isles.
- Fottea 8: 15-78.

McNeill, J.; Barrie, F.R.; Burdet, H.M.; Demoulin, V.; Hawksworth, D.L.; Marhold, K.; Nicolson, D.H.; Prado, J.; Silva, P.C.; Skog, J.E.; Wiersema, J.H. \& Turland, N.J. (2006): International Code of Botanical Nomenclature, Vienna Code. A.R.G. Gantner Verlag K.G., Ruggell, Liechtenstein.

Moravcová, A.; Beyens, L. \& Van de Vijver, B. (2010): Diatom communities in soils influenced by the wandering albatross (Diomedea exulans). - Polar Biology 33: 41-255.

Negoro, K. (1944): Untersuchungen über die Vegetation der mineralogen-azidotrophen Gewässer Japans. - Science Reports of the Tokyo Bunrika Daigaku, Section B, 6: 231-374.

Østrup, E. (1901) Freshwater diatoms. Botany of the Faeröes based upon Danish investigations. Part I. - pp. 260-290, Det Nordiske Forlag, Copenhagen \& John Wheldon \& Co., London.

Potapova, M. \& HAmilton, P.B. (2007): Morphological and ecological variation within the Achnanthidium minutissimum (Bacillariophyceae) species complex. - Journal of Phycology 43: 561-575.

PoulíčKová, A.; Veselá, J.; Neustupa, J. \& ŠKAlOUD, P. (2010): Pseudocryptic diversity versus cosmopolitanism in diatoms: a case study on Navicula cryptocephala Kütz. (Bacillariophyceae) and morphologically similar taxa. - Protist 161: 353-369.

Rohlf, F.J. (2010a): TpsDig, ver. 2. 16. - Department of Ecology and Evolution, State University New York at Stony Brook, New York.

Rohlf, F.J. (2010b): TpsRelw, ver. 1. 49. - Department of Ecology and Evolution, State University New York at Stony Brook, New York.

Round, F.E.; Crawford, R.M. \& Mann, D.G. (1990): The diatoms. Biology \& Morphology of the genera. - 747 pp., Cambridge University Press, Cambridge.

Sabbe, K.; Verleyen, E.; Hodgson, D.A.; Vanhoutte, K. \& VyVerman, W. (2003): Benthic diatom flora of freshwater and saline lakes in the Larsemann Hills and Rauer Islands, EastAntarctica. - Antarctic Science 15: 227-248.

Savriama, Y.; Neustupa, J. \& Klingenberg, C.P. (2010): Geometric morphometrics of symmetry and allometry in Micrasterias rotata (Zygnematophyceae, Viridiplantae). - Nova Hedwigia Beihefte 136: 43-54.

Savriama, Y. \& Klingenberg, C.P. (2011): Beyond bilateral symmetry: geometric morphometric methods for any type of symmetry. - BMC Evolutionary Biology 11: 280.

Tyler, P.A. (1996): Endemism in freshwater algae, with special reference to the Australian region. In: Kristiansen, J. (ed): Biogeography of 
freshwater algae. - Hydrobiologia 336: 127135.

VAn de Vijver, B. \& Beyens, L. (1999): Freshwater diatoms from Ile de la Possession (Crozet Archipelago, sub-Antarctica): an ecological assessment. - Polar Biology 22: 178-188.

Van de Vijver, B. \& Mataloni, G. (2008): New and interesting species in the genus Luticola D.G. Mann (Bacillariophyta) from Deception Island (South Shetland Islands). - Phycologia 47: 451-467.

Van de Vijver, B.; Ledeganck, P. \& Beyens, L. (2001): Habitat preference in freshwater diatom communities from Sub-Antarctic Îles Kerguelen. - Antarctic Science 13: 28-36.

Van de Vijver, B.; Frenot, Y. \& Beyens, L. (2002): Freshwater diatoms from Ile de la Possession (Crozet archipelago, Sub-Antarctica). Bibliotheca Diatomologica 46: 1-412.

VAN de ViJVer, B.; Beyens, L.; Vincke, S. \& Gremmen, N. (2004): Moss-inhabiting diatom communities from Heard Island, Subantarctic. - Polar Biology 27: 532-543.

VAN DE ViJVer, B.; Gremmen, N.J.M. \& Beyens, L. (2005): The genus Stauroneis (Bacillariophyceae) in the Antarctic region. Journal of Biogeography 32: 1791-1798.

Van de ViJver, B.; Gremmen, N.J.M. \& Smith,V. (2008): Diatom communities from the SubAntarctic Prince Edward Islands: diversity and distribution patterns. - Polar Biology 31: 795808.

Van de Vijver, B.; Chattová, B.; Metzeltin, D. \& Lebouvier, M. (2012): The genus Pinnularia (Bacillariophyta) on Ile Amsterdam (TAAF, Southern Indian Ocean). - Nova Hedwigia Beihefte 141: 201-236.

VAN DER WERFF, A. (1955): A new method for cleaning and concentrating diatoms and other organisms. - Verhandlungen der Internationalen Vereinigung für theoretische und angewandte Limnologie 12: 276-277.

Van Elslander, B.; Créach, V.; Vanormelingen, P.; Ernst, A.; Chepurnov, V.A.; Sahan, E.; Muyzer, G.; Stal, L.J.; Vyverman, W. \& SABBE, K., (2009): Ecological differentiation between sympatric pseudocryptic species in the estuarine benthic diatom Navicula phyllepta (Bacillariophyceae). - Journal of Phycology 45: 1278-1289.

Van Heurck, H. (1880): Synopsis des Diatomées de Belgique. Atlas. - pls 1-30. Ducaju \& Cie, Anvers, Belgium.

Veselá, J.; Neustupa, J.; Pichrtová, M. \& PoulíčKová, A. (2009): Morphometric study of Navicula morphospecies (Bacillariophyta) with respect to diatom life cycle. - Fottea 9: 307-316.

Vincke, S.; VAn de Vijver, B.; Ledeganck, P.; Nijs, I.
\& Beyens, L. (2007): Testacean communities in perturbed soils: the influence of the wandering albatross. - Polar Biology 30: 395-406.

Zelditch, M.L.; Swiderski, D.L.; Sheets, D.H. \& FINK, W.L. (2004): Geometric morphometrics for biologists: a primer. - 452 pp., Elsevier Academic Press, London.

Zidarova, R.; VAn de ViJver, B.; Quesada, A. \& DE HAAN, M. (2010): Revision of the genus Hantzschia (Bacillariophyceae) on Livingston Island (South Shetland Islands, Southern Atlantic Ocean). - Plant Ecology \& Evolution 143: 318-333.

(C) Czech Phycological Society (2013)

Received March 20, 2012

Accepted June 25, 2012 